\title{
Riscurile psihosociale întâlnite de salariaţi în economia digitală. Dreptul la deconectare
}

\section{The Psychosocial Risks Encountered by Employees in the Digital Economy. The Right to Disconnect}

\begin{abstract}
Alexandra-Georgiana Vâlcelaru ${ }^{1}$
Rezumat: Deşi poate fi considerată drept răspunsul la multe dintre problemele cu care se confruntă părţile unui raport de muncă, munca digitală, indiferent de forma în care este prestată, expune lucrătorii la o serie de riscuri psihosociale, de natură a vătăma sănătatea fizică şi psihică, dar şi bunăstarea acestora. Cel mai concludent exemplu este oferit de pandemia de Sars-CoV-2, care a redefinit raporturile de muncă, dar a adus în prim-plan şi problema burnoutului cu care se confruntă lucrătorii digitali. În acest context, la nivel internaţional atât statele, prin intermediul modificărilor legislative, cât şi angajatorii, prin politicile interne încearcă să diminueze acest fenomen, una dintre cele mai importante măsuri adoptate fiind reglementarea dreptului la deconectare al lucrătorilor digitali.
\end{abstract}

Cuvinte-cheie: economia digitală; telemunca; munca pe platforme; dreptul la deconectare; burnout

\begin{abstract}
Although it can be considered as an answer to many of the problems faced by the parties of an employment relationship, digital work, regardless of the form in which it is performed, exposes workers to a number of psychosocial risks, such as harm to their physical and mental health, but also to their well-being. The most conclusive example is the one provided by the Sars-CoV-2 pandemic, which redefined employment relations, but also brought to the attention the problem of the burnout syndrome faced by the digital workers. In this context, internationally, both states, through ammendments of the legislation, and employees, through internal policies try to reduce the burnout phenomenon, one of the most important measures being the regulation of the digital workers right to disconnect.
\end{abstract}

Keywords: digital economy; telework; platform work; right to disconnect; burnout

\section{Introducere}

Potrivit $\mathrm{OECD}^{2}$, „economia digitală încorporează toată activitatea economică bazată pe sau îmbunătăţită semnificativ prin utilizarea intrărilor digitale, inclusiv

${ }^{1}$ Doctorand, Facultatea de Drept, Universitatea din București, e-mail: alexandrageorgiana.valcelaru@drept.unibuc.ro

${ }^{2}$ Organisation for Economic Co-operation and Development, A roadmap toward a common framework for measuring the Digital Economy, [Online] la https://www.oecd.org/ 
tehnologii digitale, infrastructură digitală, servicii digitale şi date. Se referă la toţi producătorii şi consumatorii, inclusiv guvernul, care utilizează aceste intrări digitale în activităţile lor economice”.

În ceea ce priveşte digitalizarea, acesta reprezintă procesul de „a transforma semnalele analogice în semnale digitale” ${ }^{3}$ sau, altfel spus, reprezintă „utilizarea tehnologiilor digitale pentru a schimba un model de afaceri şi a oferi noi venituri şi oportunități de producere a valorii; este procesul de trecere la o afacere digitală"4.

Dat fiind că economia implică un ansamblu de activităţi umane desfăşurate în sfera producţiei, distribuţiei şi consumului bunurilor materiale şi serviciilor, o economie caracterizată de digitalizare implică nu doar trecerea la o afacere digitală, dar şi trecerea la o piaţă a muncii digitalizată.

Astfel, în prezent piaţa muncii este o reflexie a evoluţiei economiei, care se adaptează noilor cerinţe impuse de aceasta din urmă. Aşa cum concluzionează Eurofound ${ }^{5}$, la acest moment există nouă tipuri generale de noi forme de ocupare a forţei de muncă, dintre care două considerăm că sunt caracteristice economiei digitale, respectiv munca mobilă bazată pe tehnologia informaţiei si comunicării ${ }^{6}$ şi munca pe platformă $\breve{7}^{7}$, pe care le vom denumi generic în cele ce urmează „munca digitală ${ }^{\prime 8}$.

digital/ieconomy/roadmap-toward-a-common-framework-for-measuring-the-digitaleconomy.pdf, accesat 12.10.2021, pag 34, Arabia Saudită, 2020.

${ }^{3}$ Dicționarul Explicativ al Limbii Române, [Online] la https://dexonline.ro/ definitie/digitaliza, accesat 12.10.2021.

${ }^{4}$ Gartner Glossary, [Online] la https://www.gartner.com/en/information-technology/ glossary/digitalization, accesat 12.10.2021.

${ }^{5}$ I. Mandl, M. Curtarelli, S. Riso, O. Vargas, E. Gerogiannis, New forms of employment, European Foundation for the Improvement of Living and Working Conditions, Luxemburg, 2015: munca ocazională, job-sharing, employee-sharing, munca de portofoliu, managementul interimar, munca pe bază de vouchere, munca mobilă bazată pe tehnologia informației si comunicării, munca colaborativă și munca pe platformă.

${ }^{6}$ I. Mandl, M. Curtarelli, S. Riso, O. Vargas, E. Gerogiannis, op. cit., pp. 118-123. Munca mobilă bazată pe tehnologia informației si comunicării se referă la munca prestată cel puțin parțial, dar în mod regulat, în afara „,biroului principal”, fie că este sediul angajatorului sau un birou personalizat la domiciliu, folosind tehnologia informației si comunicării pentru conectarea online la sistemele informatice ale organizației. La nivel intern, acest tip de muncă este reprezentat de telemuncă, definită prin Legea nr. 81/2018 ca fiind „forma de organizare a muncii prin care salariatul, în mod regulat şi voluntar, îşi îndeplineşte atribuţiile specifice funcţiei, ocupaţiei sau meseriei pe care o deţine în alt loc decât locul de muncă organizat de angajator, folosind tehnologia informaţiei şi comunicaţiilor”.

${ }^{7}$ I. Mandl, M. Curtarelli, S. Riso, O. Vargas, E. Gerogiannis, op. cit., p. 107: „este o formă de muncă în care se utilizează o platformă online pentru a permite organizațiilor sau indivizilor să acceseze un grup nedefinit și necunoscut de alte organizații sau alți indivizi pentru a rezolva probleme specifice sau pentru a furniza servicii sau produse specifice în schimbul unei remunerații”. Cele mai reprezentative forme de muncă în economia de tip gig sunt munca virtuală (așa-numitul „crowdworking”) și munca colaborativă (cunoscută și ca munca la cerere prin aplicaţii).

${ }^{8}$ G. Ilie, A-M. Vlăsceanu, Poate legislația muncii să țină pasul cu noua realitate economică?, [Online] la https://www.hotnews.ro/stiri-specialisti_deloitte-23037203-poate- 
Munca digitală a fost definită la rândul său, în literatura de specialitate ca fiind „organizarea experienţei umane cu ajutorul creierului uman, a mediilor digitale şi a comunicaţiilor în aşa fel încât să fie create produse noi’’.

Având în vedere specificul său, respectiv utilizarea instrumentelor digitale ca principal mijloc de realizare a atribuţiilor, munca digitală reprezintă un avantaj important atât pentru angajatori, cât şi pentru lucrători în actualul context economic, dar şi în actualul context sanitar. $\mathrm{Cu}$ toate acestea, munca digitală implică o serie de riscuri psihosociale pentru lucrători.

\section{Beneficiile muncii digitale}

În ceea ce îi priveşte pe lucrători, un prim avantaj al muncii digitale îl reprezintă creşterea productivităţii lor, ca urmare a lipsei întreruperilor inerente muncii prestate la birou. De asemenea, aceştia se bucură de un echilibru mai bun între viaţa profesională şi viaţa personală, de reducerea stresului asociat navetei, de posibilitatea de a realiza economii ca urmare a reducerii costurilor legate de cheltuielile generate de nevoia unui vehicul, parcare sau transport public, îmbrăcăminte pentru lucru, alimente şi asigurări, dar şi de creşterea gradului de autonomie şi de flexibilitate.

Pe de altă parte, în ceea ce priveşte beneficiile aduse angajatorilor, printre acestea se numără: extinderea posibilităţii de a identifica salariaţi calificaţi, reducerea răspândirii bolilor şi posibilitatea lucrătorilor bolnavi de a-şi continua munca în afara locului lor obişnuit de muncă, reducerea costurilor, a consumului de energie şi a amprentei de carbon, posibilitatea de desfăşurare a activităţii pe mai multe fusuri orare şi creşterea adaptabilităţii culturale, reducerea fluctuaţiei personalului şi a absenteismului, acoperirea locurilor de muncă în caz de evenimente meteorologice extreme, când lucrătorii nu ar putea ajunge la locul de

\footnotetext{
legislatia-muncii-tina-pasul-noua-realitate-economica.htm, accesat 11.10.2021: „munca virtuală implică folosirea unei platforme informatice pentru a identifica persoane care utilizează Internetul (i.e. crowdsourcing) și care sunt dispuse să presteze în spațiul virtual (i.e. crowdwork) o activitate retribuită ce constă în realizarea unor sarcini rezultate din divizarea unei activități mai complexe în părți componente ce se pot realiza succesiv și foarte rapid (e.g. codificare, procesare de date și informații, descriere, clasificare, etichetare, traduceri etc.). Munca colaborativă constă în utilizarea unei platforme digitale ce poate fi accesată via computere sau telefoane mobile pentru intermedierea relațiilor dintre furnizorii de servicii (e.g. servicii de transport urban, cazare, ospitalitate, reparații sau alte servicii casnice) și beneficiarii acestora”. Așadar, diferența dintre cele două forme de muncă constă în faptul că în primul caz, activităţile sau serviciile sunt efectuate online, în schimb, în al doilea caz sunt avute în vedere activități sau servicii efectuate offline, pe baza cererii și a ofertei, care se întâlnesc prin intermediul unei aplicaţii.

${ }^{9}$ Ch. Fuchs, S. Sevignani, What is Digital Labour? What is Digital Work? What's their Difference? And why do these Questions Matter for Understanding Social Media? [Online] la https://www.triple-c.at/index.php/tripleC/article/view/461, accesat 15.10.2021.
} 
muncă ${ }^{10}$, posibilitatea exceptării de la anumite responsabilităţi impuse de lege, cum este cazul salariaţilor cu dizabilităţi, cărora nu mai este necesar să le asigure „accesibilizarea la locul de muncă"11.

\section{Riscurile psihosociale asociate muncii digitale}

În schimb, efectele asupra sănătăţii lucrătorilor pot dezechilibra balanţa efectelor pozitive anterior menţionate, printre efectele nocive ale muncii digitale fiind riscurile psihosociale asociate.

Potrivit Agenţiei Europene pentru Sănătate şi Securitate în Muncă (AESSM), „riscurile psihosociale sunt generate de conceperea, organizarea şi gestionarea precară a activității, precum şi de un context social necorespunzător la locul de muncă şi pot avea efecte negative pe plan psihologic, fizic sau social, precum stresul la locul de muncă, epuizarea sau depresia"12.

AESSM identifică şi o serie de condiţii de lucru care determină riscuri psihosociale, printre care: „volumul excesiv de muncă; cerinţele contradictorii şi lipsa de claritate privind rolul pe care îl are de îndeplinit lucrătorul; lipsa de implicare în luarea deciziilor care afectează lucrătorul şi lipsa de influenţă asupra modului de desfăşurare a activităţii; schimbările organizatorice gestionate necorespunzător, nesiguranţa locului de muncă; comunicarea ineficientă, lipsa de sprijin din partea conducerii sau a colegilor; hărţuirea psihologică şi sexuală, violenţa din partea terţilor."

În opinia noastră, o parte dintre aceste condiţii de lucru care sunt de natură să genereze riscuri psihosociale sunt adesea întâlnite şi în cazul muncii digitale, respectiv: (i) volumul excesiv de muncă, (ii) comunicarea ineficientă, (iii) lipsa de sprijin din partea conducerii sau a colegilor şi (iv) hărţuirea psihologică.

Aşa cum vom detalia în secţiunea următoare aceste condiţii sunt de natură a avea efecte negative pe plan psihologic, fizic sau social asupra lucrătorilor.

\subsection{Volumul excesiv de muncă al lucrătorilor digitali}

În ceea ce priveşte volumul excesiv de muncă, potrivit studiului OIM privind viitorul muncii şi munca pe platforme digitale ${ }^{13}$, un procent de $52 \%$ dintre respondenţi ${ }^{14}$ au raportat că au lucrat în mod regulat cel puţin şase zile pe săptămână (16\% la sută au lucrat regulat şase zile şi $36 \%$ au lucrat regulat şapte zile pe săptămână). O mare parte a lucrătorilor au lucrat în timpul nopţii (43\% în

${ }^{10}$ A. Cioriciu Ştefănescu, Telemunca, Revista Romana de Dreptul Muncii nr. 1 din 2009, [Online] la https://idrept.ro/?Form=reviste $\&$ Search=yes\&PublicationType=22, accesat 21.10.2021.

${ }_{11}$ M. E. Marica, Contracte de muncă atipice, Editura Universul Juridic, București, 2019, p. 313.

${ }^{12}$ Agenția Europeană pentru Sănătate și Securitate în Muncă, Riscurile psihosociale și stresul la locul de muncă, [Online] la https://osha.europa.eu/ro/themes/psychosocial-risksand-stress, accesat 20.10.2021.

${ }^{13} \mathrm{~J}$. Berg (coord), Digital labour platforms and the future of work. Towards decent work in the online world, International Labour Office, 2018, [Online] la https:/www.ilo.org/ global/publications/books/WCMS_645337/lang--en/index.htm, accesat 15.10.2021, p. xvi.

14 J. Berg (coord), op. cit, p. 42. 
intervalul orar 22:00 - 5:00) şi seara (68\% în intervalul orar 18:00 - 22:00), fie ca răspuns la disponibilitatea sarcinilor, fie din cauza altor angajamente. Aproximativ $18 \%$ dintre lucrători au raportat că au lucrat peste două ore noaptea timp de mai mult de 15 zile pe lună. Mai mult, aproximativ 44\% dintre lucrători au lucrat mai mult de 10 ore pe zi până la o treime din lună (1-10 zile), iar $23 \%$ dintre aceştia au avut un program îndelungat de muncă timp de 11-30 de zile într-o lună.

În schimb, telelucrătorii, bucurându-se de componenta de flexibilitate specifică telemuncii, tind să îşi „elasticizeze” timpul şi să includă pe durata programului clasic de muncă sarcini din sfera personală, de cele mai multe ori cu consecinţa prelungirii orelor de terminare a programului.

Incercarea de a suplimenta veniturile, prin prestarea unor activităţi suplimentare, în cazul lucrătorilor pe platforme sau încercarea telelucrătorilor de a-şi elasticiza timpul de muncă, fără a avea o limită maximă a numărului de ore lucrate, duce la incapacitatea individului de a-şi reface capacitatea de muncă şi de a se odihni şi recrea, funcţii specifice perioadelor de repaus garantate de legislaţia muncii.

Potrivit Rezoluţiei PE Parlamentului European din 21 ianuarie 2021 conţinând recomandări adresate Comisiei privind dreptul de a se deconecta, „numărul persoanelor din Uniune care lucrează de acasă şi care declară că au un program de lucru prelungit şi nu pot beneficia de perioadele nelucrătoare este în creştere; constată, de asemenea, că persoanele care lucrează de la distanţă în mod obişnuit sunt mai susceptibile să declare că suferă de stres profesional şi că sunt afectate de tulburări de somn, de stres şi de expunerea la lumina ecranelor digitale şi observă că alte efecte asupra sănătăţii lucrătorilor de la distanţă şi a lucrătorilor "foarte mobili" sunt durerile de cap, de ochi, oboseala, anxietate şi afecţiunile muscularo-scheletice”.

\subsection{Comunicarea ineficientă şi lipsa de sprijin din partea conducerii sau a colegilor}

În ceea ce priveşte comunicarea ineficientă şi lipsa de sprijin din partea conducerii sau a colegilor, acestea rezidă de cele mai multe ori în izolarea cu care se confruntă lucrătorul digital.

Potrivit unui interviu acordat de medicul psihiatru Prof. Dr. Manfred Spitzer ${ }^{15}$, profesor de psihiatrie la Clinica Universitară din Ulm, „ştim că forma extremă de izolare - carantina - poate duce la dereglări psihice chiar şi la persoane cu un psihic sănătos. Există studii pe termen lung care arată că, după o perioadă de carantină, oamenii se confruntă mai frecvent cu probleme cum ar fi anxietatea, insomnia sau dificultăţi în a face faţă stresului. S-a mai constatat că nu există diferenţe în acest sens între persoane tinere sau vârstnice, între bărbaţi şi femei”.

${ }^{15}$ Interviu, Prof. Dr. Manfred Spitzer, Pandemie şi carantină: Singurătatea e contagioasă, [Online] la https:/www.dw.com/ro/pandemie-\%C5\%9Fi-carantin\%C4\%83-singur\%C4\% 83tatea-e-contagioas\% C4\%83/a-52966096, accesat 17.10.2021. 
Lipsa interacţiunii şi a sprijinului din partea colegilor poate fi un factor care să conducă la burnout ${ }^{16}$, fenomen pe care îl vom analiza în secţiunile următoare.

Efecte ale izolării au loc şi în plan social. Astfel, izolarea ${ }^{17}$ este asociată cu lipsa accesului la schimbul informal de informaţii care are loc la birou, dar şi cu crearea unor bariere în carieră, deoarece mulţi lucrători la distanţă nu sunt „văzuţi” de managerii $\operatorname{lor}^{18}$.

De asemenea, izolarea duce şi la lipsa contactului direct cu clienţii, ce se concretizează în faptul că un lucrător pe platformă din trei (32\%) a raportat că are o experienţă de neplată pentru munca sa prin intermediul platformelor online.

\subsection{Hărţuirea psihologică}

În ceea ce priveşte hărţuirea psihologică, plecând de la definiţia oferită de legislaţia internă, şi anume de O.G. nr. $137 / 2000^{19}$ şi de Legea nr. $202 / 2002^{20}$ putem

${ }^{16} \mathrm{Ch}$. Aumayr-Pintar, C. Cerf, A. Parent-Thirion, Burnout in the workplace: A review of data and policy responses in the EU, European Foundation for the Improvement of Living and Working Conditions, Luxemburg, 2018, p. 16, [Online] la https:// www.eurofound. europa.eu/publications/report/2018/burnout-in-the-workplace-a-review-of-data-andpolicy-responses-in-the-eu, accesat 22.10.2021. Un factor recurent în apariția burnoutului este absența sprijinului social din partea colegilor.

${ }^{17}$ Idem, p. 17. Potrivit studiilor realizate în Marea Britanie și Bulgaria, munca în echipă reduce nivelul de burnout. În schimb, lipsa oportunităţilor de învățare și dezvoltare la locul de muncă a dovedit creșterea probabilității epuizării. Pe de altă parte, un alt factor determinant pentru burnout este rolul managementului și al conducerii, lipsa de sprijin din partea managementului crescând riscul de epuizare, pe când mentoratul, aprecierea și încrederea din conducerii are un impact pozitiv în atenuarea epuizării și menținerea sau restabilirea motivației la locul de muncă.

${ }^{18} \mathrm{Ch}$. Welz, F. Wolf, Telework in the European Union, European Foundation for the Improvement of Living and Working Conditions, 2010, p. 20, [Online] la https://www. eurofound.europa.eu/publications/report/2010/telework-in-the-european-union, accesat 23.10.2021.

${ }^{19}$ Art. 2 alin. „(51) Constituie hărțuire morală la locul de muncă și se sancționează disciplinar, contravențional sau penal, după caz, orice comportament exercitat cu privire la un angajat de către un alt angajat care este superiorul său ierarhic, de către un subaltern și/sau de către un angajat comparabil din punct de vedere ierarhic, în legătură cu raporturile de muncă, care să aibă drept scop sau efect o deteriorare a condiților de muncă prin lezarea drepturilor sau demnității angajatului, prin afectarea sănătății sale fizice sau mentale ori prin compromiterea viitorului profesional al acestuia, comportament manifestat în oricare dintre următoarele forme: a) conduită ostilă sau nedorită; b) comentarii verbale; c) acțiuni sau gesturi. $\left(5^{2}\right)$ Constituie hărțuire morală la locul de muncă orice comportament care, prin caracterul său sistematic, poate aduce atingere demnității, integrității fizice ori mentale a unui angajat sau grup de angajați, punând în pericol munca lor sau degradând climatul de lucru. În înțelesul prezentei legi, stresul și epuizarea fizică intră sub incidența hărțuirii morale la locul de muncă”.

${ }^{20}$ Art. 4 lit. $\mathrm{d}^{1}$ „prin hărţuire psihologică se înţelege orice comportament necorespunzător care are loc într-o perioadă, este repetitiv sau sistematic şi implică un comportament fizic, limbaj oral sau scris, gesturi sau alte acte intenţionate şi care ar putea afecta personalitatea, demnitatea sau integritatea fizică ori psihologică a unei persoane”. 
concluziona că în cazul muncii digitale, lucrătorii digitali se pot confrunta cu mai multe forme de hărţuire morală şi/sau psihologică, dat fiind că aceştia sunt supuşi stresului şi epuizării fizice, aşa cum vom detalia în secţiunile următoare.

În primul rând, în cazul lucrătorilor pe platforme, consecinţele negative la nivel psihologic sunt cauzate chiar de natura muncii prestate de aceştia, un exemplu concret fiind cel al lucrătorilor care moderează conţinutul site-urilor web bazate pe conţinut generat de utilizator şi elimină conţinutul semnalat ca fiind necorespunzător, pentru ca utilizatorului să-i fie prezentată o imagine relativ curată a respectivului site. Astfel, lucrătorii în cauză sunt expuşi constant la conţinut neadecvat, ce poate avea efecte psihologice pe termen lung, cum ar fi insomnie, coşmaruri, anxietate sau halucinaţii.

Pe de altă parte, majoritatea sarcinilor lucrătorilor pe platforme o reprezintă microsarcini simple şi repetitive ce nu coincid cu nivelul ridicat de educaţie al lucrătorilor, care este de natură a genera consecinţele negative pe plan psihologic menţionate anterior.

$\mathrm{Nu}$ în ultimul rând unul dintre riscurile sociale generate de munca digitală îl constituie tendinţele de exploatare ale platformelor pentru a crea o experienţă superioară pentru clienţii lor, în detrimentul lucrătorilor ${ }^{21}$, care se materializează într-un climat de lucru stresant, de natură a atrage epuizarea fizică şi psihică a lucrătorului.

$\mathrm{Cu}$ titlu de exemplu menţionăm cazul Uber, unde, dacă un pasager uită un bun în maşină în timpul cursei, şoferul îl va returna în timpul său liber, fără a fi plătit. Aceeaşi platformă oferă pasagerilor opţiunea de a plăti mai puţin dacă folosesc o călătorie comună cu alţi pasageri decât dacă folosesc o călătorie standard. Deşi pasagerii sunt avantajaţi, plătind mai puţin pentru aceeaşi cursă, acest lucru este în detrimentul lucrătorilor, care trebuie să ridice mai mulţi pasageri din diferite puncte, ceea ce duce la curse întârziate şi, deci la o experienţă mai puţin calitativă pentru pasageri. Astfel, aceştia vor avea motive să acorde şoferilor calificări slabe, lucrătorul fiind dezavantajat în detrimentul asigurării confortului pasagerului.

\section{Efectele negative ale muncii digitale asupra lucrătorului}

Toate aceste condiţii de lucru de natură să creeze riscuri psihosociale au efecte atât asupra sănătăţii fizice, cât şi a celei psihice a lucrătorilor.

\subsection{Efectele asupra sănătăţii fizice}

Printre efectele asupra sănătăţii fizice cauzate de munca digitală se numără dureri de gât şi tendon la încheieturi şi degete ${ }^{22}$ cauzate de munca pe dispozitive digitale, dureri fizice cauzate de lipsa unui spaţiu de lucru fizic adecvat şi de sedentarismul prelungit, dar şi probleme digestive ca urmare a reducerii activităţii

\section{${ }^{21}$ Ibidem.}

${ }^{22}$ A se vedea J. Messenger, O. Vargas Llave, L. Gschwind, S. Boehmer, G. Vermeylen, M. Wilkens, op. cit., p. 34. 
fizice generale şi a exerciţiilor fizice, combinate cu un aport global crescut de alimente ${ }^{23}$.

La rândul său, stresul resimţit de lucrătorii digitali menţionat în secţiunea anterioară poate cauza boli cardiovasculare şi tulburări musculo-scheletice, dar şi oboseală continuă, dureri de cap, lipsa de concentrare, lipsa de energie şi hipertensiune arterială, hipercolesterolemie, diabet de tip 2, boli coronariene, tulburări cardiovasculare, dureri musculo-scheletice, oboseală prelungită, dureri de cap, probleme gastro-intestinale, probleme respiratorii, leziuni severe şi mortalitate sub vârsta de 45 de ani ${ }^{24}$.

\subsection{Efectele asupra sănătăţii psihice}

Potrivit Rezoluţiei PE Rezoluţia Parlamentului European din 21 ianuarie 2021 conţinând recomandări adresate Comisiei privind dreptul de a se deconecta, „utilizarea excesivă a dispozitivelor tehnologice poate agrava fenomene precum izolarea, dependenţa de tehnologie, privarea de somn, epuizarea emoţională, anxietatea şi oboseala extremă; întrucât, potrivit OMS, la nivel mondial peste 300 de milioane de persoane suferă de depresie şi de tulburări de sănătate mentală comune legate de muncă şi 38,2 \% din populaţia Uniunii suferă de o tulburare de sănătate mentală în fiecare an".

În ceea ce priveşte efectele asupra sănătăţii psihice, cel mai important efect al muncii digitale este burnoutul, definit de Organizaţia Mondială a Sănătăţii ca fiind un sindrom conceptualizat ca rezultat al stresului cronic la locul de muncă care nu a fost gestionat cu succes, fiind caracterizat prin trei dimensiuni: epuizarea energiei, creşterea distanţării mentale faţă de locul de muncă sau sentimentele de negativism sau cinism legate de locul de muncă şi eficacitate profesională redusă.

Burnoutul ${ }^{25}$ are consecinţe majore pe termen lung asupra vieţii lucrătorilor. Studiile arată că lucrătorii care se confruntă cu un nivel ridicat de epuizare emoţională: au renunţat relativ des la a mai presta muncă, în decurs de doi ani (4,1\%, comparativ cu 2,3\% dintre cei care nu suferiseră de epuizare emoţională); erau, de asemenea, mai predispuşi să se afle în concediu medical pe perioade mai lungi decât ceilalţi lucrători; consideră schimbarea locului de muncă o modalitate de a scăpa de situaţia lor stresantă; îşi exprimă, de asemenea, relativ des dorinţa de a-şi reduce programul de lucru, dar de fapt nu o fac mai des decât persoanele care nu se confruntă cu epuizarea.

${ }^{23}$ X. Yijing, B.Becerik-Gerber, L. Gale, S.C. Roll, Impacts of Working From Home During COVID-19 Pandemic on Physical and Mental Well-Being of Office Workstation Users, [Online] la https://journals.lww.com/joem/fulltext/2021/03000/impacts_of_working_from_home_ during_covid_19.2.aspx, accesat 15.10.2021.

${ }^{24}$ Ch. Aumayr-Pintar, C. Cerf, A. Parent-Thirion, op. cit., p. 12.

${ }^{25}$ Idem, p. 3. Prima referire la burnout îi este atribuită lui Freudenberger, care, plecând de la definiția verbului „to burn out” („a eșua, a se uza sau a deveni epuizat ca urmare a solicitării excesive de energie, putere sau resurse"), afirma că exact același lucru se întâmplă cu un lucrător care ajunge la stadiul de burnout, devenind ineficace. Corelația ridicată dintre epuizare, depresie și anxietate este explicată de Toker și colab. (2005). 
Aşadar, burnoutul, care reprezintă unul dintre efectele asupra sănătăţii psihice a lucrătorilor digitali, are la rândul său efecte asupra sănătăţii fizice a acestora, dar şi asupra vieţii lor sociale.

\subsection{Efecte sociale}

În ceea ce priveşte efectele sociale, cel mai cunoscut efect al muncii digitale îl constituie eliminarea limitei dintre viaţa profesională şi cea personală, care poate culmina cu conflicte ale lucrătorului cu familia şi neglijarea sarcinilor casnice ${ }^{26}$. Studii efectuate în Irlanda arată că lucrătorii care au în grijă copiii de vârstă preşcolară întâmpină cele mai mari dificultăţi în concilierea vieţii profesionale cu viaţa de familie ${ }^{27}$.

Acest conflict dintre viaţa personală şi viaţa profesională poate da naştere unui stres continuu resimţit de lucrător, care, la rândul său poate cauza efectele fizice sau psihologice descrise mai sus.

Apoi, ca urmare a problemelor de sănătate ale lucrătorului, acesta absentează de la locul de muncă, ceea ce implică o serie de costuri pentru angajatori şi pentru sistemele de securitate socială, cum ar fi sistemele de invaliditate, incapacitate şi indemnizaţii de şomaj.

\section{Măsuri adoptate la nivel internaţional pentru combaterea riscurilor psihosociale asociate muncii digitale. Dreptul la deconectare}

Riscurile psihosociale şi efectele negative ale muncii digitale sunt deja cunoscute la nivel internaţional, în acest sens fiind adoptate măsuri pentru combaterea şi prevenirea acestora, atât de către state, prin adoptarea unor norme speciale, cât şi de angajatori, prin adoptarea unor politici interne.

\subsection{Măsuri adoptate la nivel legislativ, dar şi la nivel de angajatori}

O primă măsură luată de autorităţi o reprezintă monitorizarea fenomenului burnout. De exemplu, în Olanda, Inspectoratul Olandez al Muncii monitorizează un eşantion de aproximativ 2.000 de organizaţii cu privire la anumite condiţii de muncă, în 2007, în prim-plan fiind stresul legat de muncă. De asemenea, Inspectoratul bulgar de muncă, în cadrul inspecţiilor desfăşurate, a analizat dacă salariaţii angajaţii lucrează cu termene limitate strânse, dacă au experimentat presiuni de timp, agresiune sau hărţuire sau lipsă de autonomie la locul de muncă ${ }^{28}$.

O altă măsură este desfăşurarea unor campanii de informare derulate de autorităţi. Un exemplu este cel al Estoniei, unde Inspectoratul muncii a dezvoltat o

${ }^{26}$ J. Messenger, O. Vargas Llave, L. Gschwind, S. Boehmer, G. Vermeylen, M. Wilkens, op. cit., p. 36.

${ }^{27}$ A. Broughton, Work-related stress, European Foundation for the Improvement of Living and Working Conditions, Dublin, 2010, p. 14, [Online] la https://www.eurofound. europa.eu/publications/report/2010/work-related-stress, accesat 26.10.2021.

${ }^{28}$ Ibidem. 
pagină web dedicată stresului legat de muncă, care include un instrument de autoanaliză pentru companii pentru măsurarea stresului legat de muncă. De asemenea, aceeaşi autoritate a desfăşurat campanii sociale privind gestionarea stresului profesional, bazat pe bunele practici utilizate de companii la nivel naţional ${ }^{29}$. În Luxemburg există un centru de resurse pentru prevenirea şi gestionarea stresului cronic pentru a oferi îndrumări şi sprijin pentru prevenirea epuizării şi asistenţă pentru cei care suferă de epuizare ${ }^{30}$.

După monitorizare şi informarea actorilor implicaţi despre stresul la locul de muncă, atât angajatorii, cât şi autorităţile au luat măsuri de diminuare a stresului la locul de muncă. În anumite state autorităţile au adoptat măsuri în sensul facilitării obţinerii unor perioade suplimentare de repaus, în anumite condiţii excepţionale. De exemplu, în Belgia, începând din 2017 legea acordă salariaţilor posibilitatea de a dona colegilor zile de concediu către un alt salariat, pentru a facilita echilibrul între viaţa profesională şi viaţa personală a angajaţilor şi pentru a reduce epuizarea ${ }^{31}$. Acelaşi lucru este posibil şi în Franţa, însă doar pentru salariaţii care au un copil bolnav, dar şi în anumite societăţi din Italia ${ }^{32}$.

La nivel de angajatori, au fost adoptate o serie de măsuri care să sporească bunăstarea lucrătorilor, după cum urmează: Olho-Technik Czech asigură salariaţilor vitamine şi vouchere la centre de wellness, organizând totodată examinări medicale la locul de muncă; MSFT Microsoft Portugalia a oferit asistenţă psihologică gratuită pentru lucrători, masaj gratuit în timpul muncii, cofinanţarea unui club de sănătate şi a unui club sportiv (extins la membrii familiei) şi furnizarea de spaţii de fitness în cadrul spaţiilor de birouri; Slovnaft şi-a înfiinţat propria unitate psihologică pentru a ajuta la prevenirea stresului la locul de muncă, a accidentelor la locul de muncă şi a bolilor profesionale ${ }^{33}$.

\subsection{Dreptul la deconectare}

O altă măsură adoptată atât la nivel de angajatori, cât şi la nivel de autorităţi a fost reglementarea dreptului la deconectare. Orange a consacrat în Franţa, la nivel de contract colectiv de muncă în anul 2016 dreptul la deconectare. În Germania, în 2012, Volkswagen a impus ,îngheţarea” e-mailurilor în afara orelor de program, setând serverele interne să se abţină de la trimiterea de e-mailuri în conturi individuale între orele 18.15 şi $07.00^{34}$. În 2014, societatea Daimler a introdus un

${ }^{29}$ Ch. Aumayr-Pintar, C. Cerf, A. Parent-Thirion, op. cit., p. 27.

${ }^{30}$ Ibidem.

${ }^{31}$ Ch. Aumayr-Pintar, C. Cerf, A. Parent-Thirion, op. cit., p. 24.

${ }^{32}$ O. Vargas Llave; S. Boehmer, Policies to improve work- life balance, European Foundation for the Improvement of Living and Working Conditions, 2015, [Online] la https://www.eurofound.europa.eu/publications/report/2015/eu-member-states/policies-toimprove-work-life-balance, accesat 22.10.2021.

33 A. Broughton, Work-related stress, op. cit.

${ }^{34}$ European Foundation for the Improvement of Living and Working Conditions, Right to disconnect, [Online] la https://www.eurofound.europa.eu/observatories/eurwork/ industrial-relations-dictionary/right-to-disconnect, accesat 24.10.2021. 
software numit „Mail on Holiday” pe care angajaţii săi îl puteau folosi pentru a şterge automat e-mailurile primite în timp ce erau în vacanţă $\breve{~}^{35}$. În Spania, contractul colectiv al companiei încheiat la compania de asigurări AXA în iulie 2017, care stabilea dreptul angajaţilor de a-şi opri telefoanele în afara programului de lucru. Lidl din Belgia şi Luxemburg a implementat un software prin care emailurile interne care sunt trimise după ora 18:00 nu vor fi livrate destinatarului intern până la 7:00 a doua zi.

Aşa cum s-a reţinut în Rezoluţia Parlamentului European din 21 ianuarie 2021 conţinând recomandări adresate Comisiei privind dreptul de a se deconecta utilizarea instrumentelor digitale în scopuri profesionale "a dus la apariţia unei culturi de a fi „conectat în permanenţă” ",mereu online” sau „mereu de serviciu”, care poate influenţa negativ drepturile fundamentale ale lucrătorilor şi condiţiile de muncă echitabile, inclusiv remunerarea echitabilă, limitarea timpului de lucru, echilibrul dintre viaţa profesională şi cea privată, sănătatea fizică şi mentală, securitatea în muncă şi starea de bine, precum şi egalitatea dintre bărbați și femei, din cauza impactului disproporţionat asupra lucrătorilor cu responsabilităţi de îngrijire, care tind să fie femei”.

În acest sens, Parlamentul European propune consacrarea prin intermediul unei directive a dreptului la deconectare, propunând ca definiţie "a se deconecta" înseamnă a nu se implica în activităţi sau comunicări legate de activitatea profesională prin intermediul unor instrumente digitale, direct sau indirect, în afara timpului de lucru".

În viziunea Parlamentului European, statele membre ar urma să se asigure că angajatorii iau măsurile necesare pentru a le oferi lucrătorilor mijloacele necesare pentru a-şi exercita dreptul de a se deconecta şi că aceştia instituie un sistem obiectiv, fiabil şi accesibil care să permită măsurarea duratei timpului de lucru zilnic al fiecărui lucrător. Printre condiţiile minime de lucru ce ar trebui implementate la nivelul statelor membre se numără: modalităţile practice de închidere a instrumentelor digitale folosite în scopuri profesionale, sistemul de măsurare a timpului de lucru, evaluări în materie de sănătate şi securitate, inclusiv evaluări ale riscurilor psihosociale, legate de dreptul de a se deconecta, criteriile pe baza cărora se acordă angajatorilor orice derogare ${ }^{36}$ de la obligaţia de a pune în aplicare dreptul lucrătorilor de a se deconecta, criteriile de stabilire a modului în care trebuie calculată compensaţia pentru munca prestată în afara timpului de lucru, măsurile de sensibilizare, inclusiv formare la locul de muncă, care urmează să fie luate de către angajatori în ceea ce priveşte condiţiile de muncă menţionate la prezentul alineat.

${ }^{35}$ M. Gibson, Here's a Radical Way to End Vacation Email Overload, [Online] la https:// time.com/3116424/daimler-vacation-email-out-of-office/, accesat 23.10.2021.

36 Orice derogare ar urma să se acorde numai în circumstanțe excepționale, cum ar fi cazurile de forță majoră sau alte situații de urgență, și cu condiția ca angajatorul să ofere fiecărui lucrător în cauză, în scris, motive care să justifice necesitatea derogării, de fiecare dată când se invocă derogarea. 
De asemenea, potrivit propunerii de directivă, statele membre ar urma să se asigure că lucrătorii cărora le-a fost încălcat dreptul de a se deconecta au acces la mecanisme rapide, eficace şi imparţiale de soluţionare a litigiilor şi au dreptul la repararea prejudiciului în cazul încălcării drepturilor lor care decurg din prezenta directivă.

Deşi la acest moment nu există încă adoptată o astfel de directivă, o serie de state membre au adoptat măsuri legislative pentru a garanta acest drept, măsuri similare fiind luate şi la nivelul altor state din afara Uniunii Europene.

În Franţa, potrivit art. 2242-8 pct. 7 din Codul Muncii, negocierile anuale privind egalitatea profesională între femei şi bărbaţi şi calitatea vieţii la locul de muncă au în vedere procedurile pentru exercitarea deplină de către salariat a dreptului său la deconectare şi stabilirea de către întreprindere a mecanismelor de reglementare pentru utilizarea instrumentelor digitale, astfel încât să fie asigurată respectarea timpilor de odihnă şi de concediu, precum şi a vieţii personale şi de familie.

În Spania, potrivit art. 88 din Legea pentru Protecţia Datelor ${ }^{37}$, atât lucrătorii din mediul public, cât şi cei din mediul privat au dreptul la deconectare digitală astfel încât să le fie garantat, pe lângă timpul de muncă, şi respectarea timpului lor de odihnă, concediul, precum şi intimitatea lor personală şi familială. În acest sens, angajatorul, după audierea reprezentanţilor lucrătorilor, va întocmi o politică internă în care va defini modalităţile de exercitare a dreptului la deconectare şi acţiunile de formare şi conştientizare cu privire la o utilizare rezonabilă a instrumentelor digitale.

În Italia, art. 19 din Legea nr. 81/2017 38 consacră dreptul la deconectare doar în cazul prestării „muncii inteligente”, care este o modalitate de prestare a muncii stabilită prin acord al părţilor, ce implică organizare pe faze, cicluri şi obiective, fără constrângeri precise de timp sau loc de muncă, cu posibilitatea de utilizare a instrumentelor digitale pentru prestarea muncii. Astfel, munca este prestată parţial în incinta întreprinderii şi parţial în exterior, fără un loc de muncă fix şi numai în limitele duratei maxime timpului de muncă. Acordul părţilor pentru prestarea muncii inteligente trebuie să conţină perioadele de repaus al lucrătorului, precum şi măsuri tehnice şi organizatorice necesare pentru a asigura deconectarea lucrătorului de la instrumente de lucru.

Similar legislaţiei din Italia, şi în Chile ${ }^{39}$ dreptul la deconectare este consacrat doar pentru o categorie determinată de lucrători. Potrivit legislaţiei acestei ţări, în

${ }^{37}$ Ley Orgánica 3/2018, de 5 de diciembre, de Protección de Datos Personales y garantía de los derechos digitales, [Online] la https://www.boe.es/buscar/doc.php?id=BOE-A-201816673, accesat 23.10.2021.

${ }^{38}$ Legge 22 maggio 2017, n. 81 Misure per la tutela del lavoro autonomo non imprenditoriale e misure volte a favorire l'articolazione flessibile nei tempi e nei luoghi del lavoro subordinato, [Online] la https://www.gazzettaufficiale.it/eli/\%20id/2017/06/13/ $17 \mathrm{G} 00096 / \mathrm{sg}$, accesat 21.10.2021.

${ }^{39}$ Ley 21220 modifica el código del trabajo en materia de trabajo a distancia, [Online] la https://www.leychile.cl/Navegar?idNorma=1143741, accesat 21.10.2021. 
cazul lucrătorilor la distanţă care îşi stabilesc singuri programul de muncă şi în cazul telelucrătorilor excluşi de la limitarea programului de lucru, angajatorul trebuie să respecte dreptul acestora la deconectare, garantându-le un timpul în care nu vor fi obligaţi să răspundă la comunicări, ordine sau alte cerinţe ale angajatorului.

Legislaţie din Chile merge însă mai departe decât legislaţia din Italia şi prevede că timpul de deconectare trebuie să fie de cel puţin douăsprezece ore continue într-o perioadă de douăzeci şi patru de ore. De asemenea, în niciun caz angajatorul nu poate transmite comunicări, ordine sau alte cerinţe în timpul zilelor de concediu ale lucrătorilor.

În mod similar în Argentina $a^{40}$, potrivit art. 5 din Legea 27.555 privind telemunca, telelucrătorul are dreptul de a se deconecta de la dispozitivele digitale şi/sau tehnologiile informaţiei şi comunicaţiilor, în afara programului său de lucru şi în perioadele de concediu. Legea prevede expres că telelucrătorul nu poate fi sancţionat pentru exercitarea acestui drept.

În Slovacia, potrivit modificărilor Codului Muncii care au intrat în vigoare de la 1 martie $2021^{41}$, salariatul care desfăşoară activităţi casnice şi telelucrătorul au dreptul la repaus zilnic şi săptămânal neîntrerupt, cu excepţia cazului în care aceştia prestează muncă on-call sau muncă suplimentară. Astfel, angajatorul nu poate considera că refuzul salariatului de a presta munca în aceste perioade reprezintă o încălcare a obligaţiilor contractuale.

În schimb, în Belgia, potrivit Legii privind întărirea creşterii economice şi coeziunii sociale, pentru a asigura respectarea perioadelor de repaus ale lucrătorilor şi pentru a menţine echilibrul dintre muncă şi viaţa privată, angajatorul organizează consultări în cadrul Comitetului pentru Prevenire şi Protecţie în Muncă cu privire la deconectarea de la locul de muncă şi utilizarea mijloacelor digitale de comunicare ${ }^{42}$. Aşa cum s-a arătat în literatura de specialitate ${ }^{43}$,angajaţii din Belgia au dreptul de a discuta cu angajatorii lor chestiunile referitoare la deconectare, dar nu au dreptul la deconectare în sensul strict al termenului. Angajatorul poate să adopte politici de deconectare după ce se consultă cu comitetul, dar nu este obligat să facă asta”.

${ }^{40}$ Régimen legal del contrato de teletrabajo, Ley 27555, [Online] la https:// www.boletinoficial.gob.ar/detalleAviso/primera/233626/20200814, accesat 21.10.2021.

41 Zákonník Práce [Online] la https://www.slov-lex.sk/pravne-predpisy/SK/ZZ/2001/ 311/ 20210301.html\#paragraf-52.odsek-10, accesat 21.10.2021.

${ }^{42}$ Loi relative au renforcement de la croissance économique et de la cohésion sociale, [Online] la https://www.ejustice.just.fgov.be/ cgi_loi/change_lg.pl?language $=$ fr\&la= F\&table_name $=$ loi\&cn $=2018032601$, accesat 21.10.2021.

${ }^{43}$ L.Dima, A. Högback, Legiferarea dreptului la deconectare, Friedrich-Ebert-Stiftung, România, 2020, [Online] la http://library.fes.de/pdf-files/bueros/bukarest/17026.pdf, accesat 21.10.2021. 
Un exemplu similar este cel al Irlandei, cel mai recent stat care a consacrat dreptul la deconectare, în acest caz însă, prin intermediul unui Cod de Practică ${ }^{44}$ ce stabileşte îndrumări şi bune practici pentru angajatori şi angajaţi în ceea ce priveşte respectarea legislaţiei muncii.

Potrivit acestui Cod, dreptul la deconectare implică trei aspecte principale: (i) dreptul unui lucrător de a nu presta în mod regulat muncă în afara programului normal de lucru; (ii) dreptul unui lucrător de a nu fi penalizat pentru refuzul de a presta munca în afara programului normal de lucru şi (iii) obligaţia de a respecta dreptul altei persoane la deconectare (de exemplu, obligaţia de a nu trimite emailuri sau de a nu telefona în mod obişnuit în afara programului normal de lucru).

În acest sens, sunt prevăzute o serie de obligaţii atât pentru angajator, cât şi pentru lucrător. În ceea ce priveşte angajatorul, acesta are obligaţia de a informa lucrătorii cu privire la durata timpului de muncă, de a se asigura că aceştia beneficiază de perioadele de repaus, de a asigura un mediu de lucru sigur şi de a nu sancţiona niciun lucrător care îşi exercită drepturile prevăzute de lege în materie de sănătate şi securitate în muncă. Pe de altă parte, lucrătorii au obligaţia de a se asigura că îşi gestionează în mod corespunzător timpul de muncă, de a respecta legislaţia în materie de sănătate şi securitate în muncă, de a înregistra timpul de lucru prin intermediul mecanismelor puse la dispoziţie de angajator, de a respecta dreptul colegilor la deconectare, de a-şi notifica în scris angajatorul cu privire la orice perioadă de repaus la care sunt îndreptăţiţi şi de care nu pot beneficia, de a avea grijă de bunăstarea lor legată de muncă şi de a lua orice măsuri de remediere, dacă este necesar.

De asemenea, Codul promovează o serie de reguli în materie de comunicare: indicarea programului normal de lucru al salariatului în cadrul semnăturii ataşate emailului, crearea unor răspunsuri automate de tip „out of office” şi la încheierea programului de muncă, nu doar pe durata concediilor.

\section{Propuneri de lege ferenda}

Având în vedere efectele negative psihosociale pe care munca digitală le are asupra lucrătorilor, considerăm utilă legiferarea unor măsuri care să prevină şi să combată aceste efecte.

În primul rând, este necesară modificarea legislaţiei naţionale şi adaptarea acesteia la realităţile economice şi sociale. Un prim pas ar fi reglementarea muncii digitale, care în ceea ce ne priveşte, poate fi definită ca acea formă de prestare a muncii prin care lucrătorul îşi îndeplineşte atribuţiile specifice funcţiei, ocupaţiei sau meseriei pe care o deţine folosindu-se preponderent de instrumente digitale.

Având în vedere specificul acestui tip de muncă, precum şi riscurile psihosociale inerente, se impune totodată reglementarea unor măsuri de combatere a acestor riscuri. În opinia noastră acestea ar trebui să aibă în vedere condiţiile de

\footnotetext{
${ }^{44}$ Code of practice for employers and employees on the right to disconnect, [Online] la https://workplacerelations.ie/wrc/en/what_you_should_know/codes_practice/code-ofpractice-for-employers-and-employees-on-the-right-to-disconnect.pdf, accesat 21.10.2021.
} 
lucru care sunt caracteristice muncii virtuale şi care, aşa cum a reţinut AESSM sunt asociate riscurilor psihosociale.

În ceea ce priveşte combaterea volumului excesiv de muncă al lucrătorilor digitali, considerăm utilă instituirea obligaţiei angajatorilor de a adopta proceduri care să asigure respectarea duratei maxime a timpului de lucru. Aşa cum s-a arătat şi prin Rezoluţiei Parlamentului European din 21 ianuarie 2021 conţinând recomandări adresate Comisiei privind dreptul de a se deconecta „înregistrarea eficace a timpului de lucru poate contribui la respectarea timpului de lucru stabilit prin contract" 45 .

În acest sens, recomandăm promovarea unei culturi care să permită lucrătorului deconectarea de la mediul de lucru în afara perioadei de lucru, materializată prin organizarea muncii şi a volumului de muncă ţinând cont de numărul personalului disponibil, consacrarea unor obiective realizabile fără o conexiune a lucrătorului în afara programului de muncă, lipsa de sancţiune a lucrătorilor care nu pot fi contactaţi în afara programului de muncă.

Totodată, deşi criticat în practică ${ }^{46}$, un instrument util pentru respectarea duratei timpului de muncă, dar şi pentru reducerea stresului la locul de muncă, şi implicit al combaterii hărţuirii psihologice o constituie reglementarea dreptului la deconectare.

Similar prevederilor Codului de practică din Irlanda, considerăm util ca prin reglementarea dreptul la deconectare, să se încurajeze atât respectarea acestui drept, dar să se ţină cont şi de flexibilitatea necesară pentru desfăşurarea anumitor activităţi, astfel încât să nu instituie restricţii ale modelelor de comunicare şi să se permită contactarea lucrătorilor în afara programului de lucru, cu titlu ocazional şi doar justificat de motive obiective.

${ }^{45}$ Rezoluția Parlamentului European din 21 ianuarie 2021 conținând recomandări adresate Comisiei privind dreptul de a se deconecta (2019/2181(INL)), [Online] la https:// www.europarl.europa.eu/doceo/document/TA-9-2021-01-21_RO.html\#sdocta7, accesat 20.10.2021.

${ }^{46} \mathrm{~S}$. Glaveski, Why the right to disconnect is a bad idea, [Online] la https://www. thehrdirector.com/features/future-of-work/why-the-right-to-disconnect-is-a-bad-idea/, accesat 27.10.2021. După consacrarea legislativă a acestui drept și punerea lui în practică, au fost însă identificate și o serie de dezavantaje ale acestui drept. Lucrătorii susțin că legislația nu poate schimba modul de desfășurare a businessurilor internaţionale, care implică fusuri orare diferite, dar şi un grad ridicat de competitivitate între salariaţi, deci implică nevoia de prestare a muncii și „după ora 18:00”. În acest sens, se propune o modificare a modalității de prestare a muncii, respectiv o trecere la o „comunicare asincronă”, caracterizată de sintagma „Voi presta munca atunci când îmi convine”, ceea ce se materializează în perioade de timp neîntrerupte în care lucrătorii pot efectua presta munca într-o stare de concentrare maximă, ceea ce se traduce prin productivitate crescută. Autorul articolului atrage totodată atenția asupra activităților neimportante care consumă foarte mult din timpul lucrătorului (utilizarea ședințelor, a emailurilor), când există metode mult mai eficiente pentru a organiza activitatea lucrătorilor, cum este cazul aplicațiilor de organizare a proiectelor. 
De asemenea, reglementările ar trebui să ţină cont de cazul lucrătorilor care lucrează în multinaţionale şi, deci care ar putea fi contactaţi de colegi care lucrează pe alte fusuri orare, în acest caz fiind necesară adoptarea unor reguli clare cu privire la exercitarea dreptului la deconectare şi, implicit la perioada de timp în care lucrătorul ar trebui să răspundă comunicărilor în acest caz.

$\mathrm{O}$ altă măsură pentru combaterea fenomenului hărţuirii psihologice o constituie obligarea angajatorilor de a adopta proceduri de training atât pentru lucrători, cât şi pentru manageri cu privire la caracteristicile muncii digitale, riscurile asociate şi potenţialele efecte negative. Pe de o parte, s-ar creşte gradul de încredere al managerilor în lucrătorii digitali, s-at facilita procesul de comunicare dintre aceştia, rezolvându-se inclusiv problema izolării lucrătorului digital.

Totodată, actorii implicaţi ar trebui să beneficieze de instruire cu privire la modul de respectare a regulilor privind timpul de lucru şi a regulilor de muncă specifice muncii digitale, inclusiv cu privire la modul de utilizare a instrumentelor digitale, dar şi a riscurilor de a fi conectaţi excesiv.

$\mathrm{Nu}$ în ultimul rând, având în vedere efectele asupra sănătăţii psihice a lucrătorilor, considerăm necesară adoptarea de urgenţă a unor măsuri de combatere a stresului şi burnoutului la locul de muncă.

În primul rând, se impune recunoaşterea burnoutului ca boală profesională ${ }^{47}$, cu consecinţa imediată a monitorizării fenomenului la nivel naţional. Această monitorizare ar permite autorităţilor în materie să contureze unele strategii pentru prevenirea stresului la locul de muncă şi, implicit a burnoutului.

Menţionăm că, la acest moment, potrivit rezultatelor cercetării noastre, există o pagină web dedicată burnoutului ${ }^{48}$, unde există posibilitatea de testare a nivelului de burnout resimţit, sunt prezentate articole de specialitate în materie şi se acordă consiliere online, acesta fiind un proiect finanţat prin Programul Operaţional Capital Uman 2014 - 2020 / Axa Prioritară 3: Locuri de muncă pentru toţi / POCU/82 „România Start Up Plus” .

De asemenea, ţinând cont de rezultatele acestei monitorizări, propunem legiferarea obligaţiei angajatorului de a oferi lucrătorului o serie de beneficii pentru a preveni şi combate stresul la locul de muncă şi burnoutul, cum se întâmplă deja la nivel european.

Vidul legislativ actual şi lipsa oricăror iniţiative cu privire la munca digitală echivalează, în opinia noastră, cu îngrădirea dreptului la muncă pentru lucrătorii digitali, atât timp cât aceştia sunt expuşi unor riscuri ridicate în cazul prestării acestei forme de muncă. Se impune, aşadar, iniţierea cât mai rapidă a unor proceduri şi adoptarea unor măsuri în consecinţă, pentru a răspunde nevoilor societăţii de astăzi pentru care legislaţia tradiţională nu mai este suficientă.

Aşa cum spunea A. Basilescu, „Munca este o condiţie a vieţii. O suspendare, fie şi parţială a muncii, paralizează organismul social şi periclitează viaţa indivizilor,

47 În anumite țări din Europa legislația are în vedere reglementarea burnoutului ca boală profesională (e.g. Italia, Letonia, Olanda, Bulgaria doar în anumite sectoare de activitate). A se vedea Ch. Aumayr-Pintar, C. Cerf, A. Parent-Thirion, op. cit., p. 9.

${ }^{48}$ A se vedea [Online] https://burnouthub.ro/, accesat 28.10.2021. 
iar încetarea ei totală, fie şi numai o săptămână, ar constitui o imensă catastrofă, asemănătoare cu cele inventate de romancieri pentru a descrie sfârşitul lumii. Inactivitatea este clar sinonimă cu moartea"49.

\section{Referințe}

Aumayr-Pintar Ch., Cerf C., Parent-Thirion A., Burnout in the workplace: A review of data and policy responses in the EU, European Foundation for the Improvement of Living and Working Conditions, Luxemburg, 2018

Berg J. (coord), Digital labour platforms and the future of work. Towards decent work in the online world, International Labour Office, 2018

Broughton A., Work-related stress, European Foundation for the Improvement of Living and Working Conditions, Dublin, 2010

Cioriciu Ştefănescu A., Telemunca, Revista Romana de Dreptul Muncii nr. 1 din 2009

Dima L., Högback A., Legiferarea dreptului la deconectare, Friedrich-Ebert-Stiftung

European Foundation for the Improvement of Living and Working Conditions, Right to disconnect

Fuchs Ch., Sevignani S., What is Digital Labour? What is Digital Work? What's their Difference? And why do these Questions Matter for Understanding Social Media?

Gibson M., Here's a Radical Way to End Vacation Email Overload

Ilie G., Vlăsceanu A-M., Poate legislaţia muncii să ţină pasul cu noua realitate economică?

Mandl I., Curtarelli M., Riso S., Vargas O., Gerogiannis E., New forms of employment, European Foundation for the Improvement of Living and Working Conditions, Luxemburg, 2015

Marica M.E., Contracte de muncă atipice, Editura Universul Juridic, Bucureşti, 2019

Organisation for Economic Co-operation and Development, A roadmap toward a common framework for measuring the Digital Economy, Arabia Saudită, 2020

Spitzer M., Pandemie şi carantină: Singurătatea e contagioasă

Ştefănescu I.T., Tratat teoretic şi practic de drept al muncii, Universul Juridic, Bucureşti, 2014

Vargas Llave O., Boehmer S., Policies to improve work-life balance, European Foundation for the Improvement of Living and Working Conditions, 2015

Welz Ch., Wolf F., Telework in the European Union, European Foundation for the Improvement of Living and Working Conditions, 2010

Yijing X., Becerik-Gerber B., Gale L., Roll S.C., Impacts of Working From Home During COVID-19 Pandemic on Physical and Mental Well-Being of Office Workstation Users

${ }^{49}$ A. Basilescu apud I.T. Ștefănescu, Tratat teoretic și practic de drept al muncii, Universul Juridic, București, 2014, p. 13. 
